UDC 811'111'373.2

DOI https://doi.org/10.32841/2409-1154.2020.45-2.15 Havryliuk O. O.,
Candidate of Philological Sciences,
Assistant Professor at the Department of English Philology and Intercultural Communication
Taras Shevchenko National University of Kyiv

Nikiforova Ye. Yu., Candidate of Philological Sciences, Assistant Professor at the Department of English Philology and Intercultural Communication Taras Shevchenko National University of Kyiv

\author{
Halytska Ye. A., \\ Candidate of Philological Sciences, \\ Teacher of English and German \\ Kyiv Gymnasium № 86 "Konsul”
}

\title{
MARKING BEARERS OF SOCIAL STRATIFICATION SEMANTICS IN PERFUME AND COSMETIC NAMES
}

Summary. The article deals with the problem of perfume and cosmetic names in English and offers a new approach towards the semantics of naming units. Special attention is given to the social stratification reflection in the naming units, involving marking bearers which reveal the presence of social stratification. The marking bearers are viewed as discrete naming-structural components or component clusters, having in the naming units specific speech realization and arrangement. At the same time, these marking bearers are carriers of certain functional load connected with the forming of naming units in their semantic aspect. These marking bearers (within the speech aspect of perfume and cosmetic frame) are semantic-structural and content-narrative reflection of the naming units. In the narrow sense, the marking bearers are concentrated around two hypergroups. The first hypergroup is associated with biosocial features; the second one is connected with socio-segmentation characteristics. The first hypergroup is divided into two groups separated into four subgroups. The first subgroup consists marking bearers of age, the second one - gender marking bearers, the third subgroup includes marking bearers of social status and the fourth one is created with marking bearers of professional activity. In the broader sense marking bearers may be understood as symbolic ones reflecting social stratification in an implicit way. This way marking bearers with symbolic connotation are concentrated around two groups. The first group grasps object symbols and the second group includes personal name symbols. Object symbols are divided into subgroups of toponyms and gemonyms. Personal name symbols are divided into subgroups of real person names and metonyms. The usage of dictionary definitions of symbolic marking bearers makes it possible to identify archesemes, differential semes. These semes are basic criteria for further grasping symbolic marking bearers into corresponding groups and subgroups.

Key words: archesemes, differential seme, marking bearer, naming unit, perfume and cosmetic names, semantics, social stratification.

Statement of the problem. The main problem of perfume and cosmetic goods is difficulty in naming the smell, aroma, odour, fragrance involving traditional verbal way. Perfume and cosmetic naming is called for reflecting olfactory preferences of the potential consumers, giving further information about the social stratification of future users, consumers of these goods.

Analysis of the recent researches and publications. Attempts to investigate the social factor verbalization and representation in the sphere of naming units connected with perfume and make-up goods look a bit disconnected and focused on the narrow aspect of the problem without the deep penetration into the inner specification of that linguistic object. The perfume market processes are analyzed considering the pyramidal shape structure where the top is built up with the perfume selective cluster; and the basement is built up with the goods of global companies (L'Oreal, $P \& G$ ) which possess a lot of brands in their portfolios. Social preferences seem to have been changed under the influence of megabrands and presentday patterns of beauty [8, p. 899-901]. The main feature of perfume goods is connected with the tendency of strong aroma resemblance which is proclaimed "tyranny of identity" [7, p. 14-16]. Revived old traditions and recipes are reflected and realized in artistic perfumes. Creation of new and revival of old fragrances are said to have become the alternative way of "sad", "plain", "common" smells of consumer goods [13, p. 682-684]. Artistic (selective, premium) perfumes being associated with the top-quality level do not require direct advertisement, and online advertising is known to be involved in that case [16, p. 26]. The usage of manufacturers' names as basic indicators is known to have had a very old tradition. It is recognized as personal responsibility for high quality. That way could be traced in the oldest perfume companies: Greed (founded in 1760), Houbigant (founded in 1775), Guerlain (founded in 1828). Guerlain was involved in the manufacture of cosmetic goods and only later it created its own perfumery [1, p. 27]. Myth creation led to brand destruction and its gradual turning into ordinary consumer goods. Between 1968-1978 perfume Chanel № 5 is known to have been sold everywhere in the USA, even in the drugstores [8, p. 898]. The process of nomination includes two steps. The first one is nomination in proper (creating, forming the name of goods) and juridical support, assistance $[10$, p. 69-70]. Functions of the brand name market are 
very substantial. As any brand name belongs to the consumers' memory, it should be effortless and comfortable for pronunciation remembering, memorizing and having sense [14, p. 194]. The goods name having a definite sense helps customers to identify, remember and recognize the brand [9, p. 51]. Brand names should be connected with the category of goods; moreover, they should create a mental image in the consumers' brain [2, p. 197]. The brand name should be functional and have strong positive associations or connotations, a stable symbolic sense [15, p. 66]. Brand name characteristics (as a collection of features) should reflect all product properties as being connected with the marketing support of desirable image [2, p. 201]. Textuality standards have been investigated in the corpus of lipstick brand names. It resulted in separating 14 classification groups [12, p. 596-597]. That underlines and outlines the integrity and complex nature of make-up names. Harrison's ideas about perfume and cosmetic names are connected with potential consumers who are abandoned to create their own image situations, using linguistic associations as a sense of direction [7, p. 8].

Sporadic investigations in the sphere of perfume and cosmetic naming demonstrate that the social factor has not been the central subject of the linguistic studies and needs further and systematic improvement. The lack of social stratification research in the area of perfume and cosmetic names was partly covered and compensated with the aspect of social stratification verbalization [6], but the semantic aspect was out of linguistic research. This sphere needs in-depth investigation as it may reveal denotative and connotative meanings within the lexical meaning of perfume and cosmetic names in the aspect of social stratification.

The purpose of the article is the investigation of perfume and cosmetic names taking into consideration the social stratification representation in the naming units. The target of the article is the detailed investigation of verbal reflecting the social stratification in the naming units of perfume and cosmetic goods.

The scientific novelty lies in the fact that social stratification in naming procedures is not investigated profoundly, particularly in the sphere of perfume and cosmetic naming. The object of the investigation is the social stratification verbalization in the system of goods names and the ways of social stratification semantics reflection in nominative units. The subject of the research is the set of naming units used in the English language for naming perfume and cosmetic goods.

Presentation of the main material. Perfume and cosmetic naming space is represented with the perfume and cosmetic names which function as naming units - bearers of information about corresponding goods. Naming units consisting of corresponding lexical units are the targets for detailed investigation of the social aspect. The social aspect of this research should involve analyzing naming units. Semantic filling (core) of perfume and cosmetic naming units (with the aim of finding social reflection) may be investigated by analyzing lexical units - words which act as functioning components of marking bearers. These marking bearers are recognized as focal points taking place in the whole naming unit reception program. Marking bearers are identified as discrete naming structural components (a discrete marking bearer - individual lexical unit Gentleman or an association - cluster-word combination Bod Man Warrior). They all obtained speech realization and arrangement in the naming unit. At the same time, these marking bearers carry a primary or secondary load from the point of creating naming units in their semantic aspect. Marking bearers point out (in the frame of speech aspect of perfume and cosmetic goods names) at the concrete semantic-structural and substantial-narrative manifestation of that naming unit. It is a social factor that should be analyzed using marking bearers of anthropological meaning, in particular, the subgroup of social feature differentiation. Social features are different, such as sex and gender, nationality, ethnos, age, social status; educational and property qualification) are far from the biological background. Such semantic diffusion requires thorough analysis in the sphere of social features which may be reflected in the perfume and cosmetic names. Penetration into the semantic space of perfume and cosmetic names gives the possibility of identifying gender differentiation in naming units (Femme; Republic of Women; Bulgari Pour Femme; Pour Femme; Dior Homme Intense; Men's Collection Citrus; Evidence Homme Green; Diamonds for men; Rocky Man Silver; Bod Man Silver; Bulgari Man in Black; Dior Homme Parfum). Gender marking bearers (women, femme, men's, man, and homme) represent gender specification in an explicit way and age differentiation in an implicit way. These lexemes are associated with adults but not children and have their semantic antagonists connected in an explicit way with younger generations (Baby Doll; Volume Effect Fauxcils Baby Doll). Age and gender marking bearers (singled out in the naming units) form a biosocial group because gender and age marking bearers have a common biological semantic background that is the reason of their grouping within the sphere of that group. Marking bearers of the biosocial group have their semantic antagonist which may be qualified as a group of social stratification. That group grasps two subgroups of marking bearers. Within the naming units - perfume and cosmetic names (Bod Man Warrior; Bod Man Prayer; Road Runner; On Duty women; On Duty men sport; On duty men active; Dior Homme Sport; professional hair color; Professional eye smokifier; professional kohl eyeliner; Maestro; Sport for women; Futurist; Perfectionist; Idealist; Lip maestro; Tycoon; T-LAB professional; Hair Concept professional HC; label.m professional haircare) lexical units for underlying professional and occupation activity (professional, maestro, warrior, player, runner, on duty) are recognized as professional activity marking bearers of explicit and implicit (futurist, perfectionist, idealist) meaning. Marking bearer Tycoon is the intermediate, transitional point-link between professional activity marking bearers and social stratification ones. Social stratification marking bearers are represented in perfume and cosmetic names (Gentleman; Elite Gentleman; Gentleman only Intense; Berlin playboy; Disney Princesse; Prince Mat chabelli; French White Musk; Lady Million Eau My Gold; L'imperatrice; Emporio Armani; Killer Queen; Royal Aqua; Cuba Royal; Royal Velvet) as lexical units (gentleman, lady, prince, princess, queen, l'imperatrice). Meanwhile, these marking bearers show the gender difference but it is the reflection of the secondary semantic component (if we compare with the primary semantic component of lexical units man, woman). The narrower sense principles of grouping form separate four individual subgroups of marking bearers representing the background of social stratification in perfume and cosmetic names. There are subgroups of marking bearers with age and gender identifications. They are connected with the group of biosocial differentiation. Subgroups of marking bearers with social status and professional activity indications are united in the group of social stratification. The groups of biosocial differentiation and social stratification are recognized as a hyper group of explicit meaning concerning the social stratification features. The explicitness 
of the meaning may be emphasized using the method of dictionary definitions. Adjective ROYAL is separated as a marking bearer in naming units: Eau de Royal Secret; Cuba Royal; Royal Copenhagen; Royal Aqua; Royal Velvet. Its dictionary definition demonstrates the connections of that lexical unit with the highest social levels: "relating to or belonging to a king or queen, (informal) a member of a royal family" [11, p. 1436]. There are some semantically related marking bearers in the naming units: Killer Queen, Prince Matchabeli; French Musk; Disney Princess(e); L'imperatrice. All of them belong to the status vocabulary. Dictionary definitions clarify their lexical meaning: Queen "the female ruler of a country; the wife of a king" [11, p. 1342]; Prince "the son of a king, queen or prince; a male ruler of a small country or a state" [11, p. 1300]; Princesse "a close female relation of a king and queen, especially a daughter; the wife of a prince" [11, p. 1301]. Perfume nominators used the French spelling of that lexical unit, and they did Gallicism L'imperatrice with the purpose of giving the French charm to the whole naming unit. That example has a strong semantic resemblance with the naming unit Emporio Armani where the Gallicism emporio corresponds to the assimilated lexical unit empire: "a group of countries that are all controlled by one ruler or government; a group of organizations controlled by one person" [11, p. 512]. The lexical unit which functions as the social status marking bearer Gentleman occurs in the structure of naming units: Elite Gentleman; Gentleman only; Gentleman only intense. The semantics of that lexical unit shows its belonging to the status lexicon: Gentleman "a polite word for a man used especially talking to or about a man you do not know; a man who is always polite, has good manners, and treats other people; (old-fashioned) a man of a high social class, especially one whose family owns a lot of property" [11, p. 672]. Lexical unit Lady within the naming unit Lady Million Eau my Gold also belongs to the indicators of social status and has a corresponding dictionary definition: "a woman of a particular type of age; a woman who is polite and behaves very well; uses the title of the wife or daughter of a British nobleman or the wife of a knight; (old-fashioned) a woman born into a high social class in Britain" $[11$, p. 899]. In the naming unit Berlin Playboy the lexical unit Playboy belongs to the status lexicon according to its dictionary definition: "a rich man who does not work and who spends his time enjoying himself with beautiful women, fast cars etc." [11, p. 1253]. The dictionary definition of the adjective Elite being the component of the naming unit Elite Gentleman shows its connection with the status lexicon: "(n.) a group of people who have a lot of power and influence because they have money, knowledge or special skills; (adj.) an elite group contains the best, most skilled or most experienced people or members of a larger group" [11, p. 508-509]. In the naming unit Love of Glamour lexical unit Glamour is connected with status lexicon too: "the attractive and exciting quality of being connected with wealth and success; a style of attractiveness that suggests wealth" [11, p. 684]. That group of social status marking bearers grasps lexical units connected with property status, property relations and property qualification on the basis of the title, social hierarchy. Another group of marking bearers closely connected with the previous one may be described as a professional activity marking bearers. They also demonstrate the relation with the same property status, property relations and property qualification, but the basis of these relations is a bit different. Instead of the title, social hierarchy, the background of professional activity marking bearers is business, hierarchy in the business circles, suc- cess in business-like cooperation. The lexical and simultaneously naming unit Tycoon has a very clear professional semantics: "someone who is successful in business or industry and has a lot of money and power" [11, p. 1793]. Professional activity marking bearers may underline the level of professional skill, as Maestro: "someone who can do something very well, especially a musician" [11, p. 989]. ThenamingunitBodman Warriorunderlinesthespecification ofactivity, and the nominator connects the potential user with that quality which is revealed in the dictionary definition Warrior: "a soldier or fighter who is brave and experienced - used about people in the past" [11, p. 1857]. In the naming unit Bod man Player lexical unit Player demonstrates its meaning in the dictionary definition: "someone who takes part in a game or sport; one of the important people; company, country etc. that is involved in and influences a situation, especially one involving competition; a man who has sexual relationships with many different women" [11, p. 1253]. The last definition demonstrates some semantic relation between two naming units: Bod man Player and Berlin Playboy. That relation is based on the type of carefree life, vanity of vanities. Within the professional activity indicators, there is a subgroup connected with sport as a professional activity. It is possible to find lexical unit Sport in this nominative unit subgroup: Sport for Women; On duty men sport; Dior Homme Sport. The dictionary definition identifies that type of activity as a professional one: "a game, competition, or activity needing physical effort and skill that is played or done according to rules, for enjoyment and/or as a job" [11, p. 1600]. There are some other naming units connected semantically with the subgroup of sport: Mustang Sport; Road Runner. The dictionary definition of the lexical unit Runner reveals its belongings to that subgroup too: "a person who runs competitively as a sport or hobby" [11, p. 1444]. The naming unit Master Corrector has two lexical units connected with the high professional skill, qualification, master: "a person who is very skilled in a particular job activity" [11, p. 1012]; corrector: "apart from the general sense of anyone who corrects mistakes, it has been used as, or part of (some commonly shortened again to corrector), various specific titles and offices, sometimes quite distant from the original meaning" [11, p. 351]. The naming unit Guardians of love has the lexical unit semantically related to indicators of professional activity, Guardian: "someone who guards or protects something" [11, p. 719]. Some other naming units belong to that group too according to their dictionary definitions, Perfectionist: "a person who wants everything to be perfect and demands the highest standards possible" [11, p. 1220]. Idealist: "someone who tries to live according to high standards or principles, especially in a way that is not practical or possible" [11, p. 844]. Futurist belongs to this group too. The cluster of naming units On Duty woman; On Duty men sport; On Duty men active contains the lexical unit duty belonging to the professional activity marking bearers with the general meaning, duty: "something you have to do as part of your job"; be on duty: "to be working at a particular time, especially when you are doing a job which people take turns to do so that someone is always doing it" [11, p. 490]. Professional activity marking bearers are created by involving professional terminology which shows the professional activity. Haute-Couture: "the design and production of expensive and fashionable clothes, or the clothes themselves" [11, p. 361]. Another constellation of naming units (Berrywell professional haircare; Esteel professional; professional eye smokifier; professional Kohl eyeliner) operates with the lexical unit professional. Its dic- 
tionary definition demonstrates the meaning: "relating to a job that needs special education and training; relating to your job or work and not to your private life; doing a job, sport, or activity for money, rather than just for fun; someone who works in a profession, or who has an important position in the company or business" [11, p. 1308]. Social stratification marking bearers contain archenemies power, money, wealth, success. It shows that they are grouped around the property status, property relations, and property qualification. On the background of differential semes, that group is divided into two subgroups. The first subgroup grasps social status marking bearers; they are gathered together having differential semes high social class; high social position; the ruler of the country; a member of a royal family. The second subgroup contains professional activity marking bearers; all of them have the differential seme job which underlines not the money and power inheritance but the way of obtaining money and power by a business. These two subgroups are determined with the aggregate of semes. The semes are in the lexical units forming corresponding perfume and cosmetic naming units (a member of the royal family; the ruler of a country; a high social class; a high social position; family owns a lot of property; born into a high social class; a rich man; who has a lot of power/ money; being connected with wealth and success; successful in business or industry and has a lot of money and power; can do something very well; one of the important people; played or done as a job; very skilled in a particular job; to do as part of your job; doing a job; to have powers; to be good at something; a job that needs special education). This way of social stratification verbalization may be defined as explicit. Explicitness consists of the naming units, lexical units used for the process of verbalization. These units have a set of direct meaning semes connected with the social stratification. This sphere is connected with a property qualification. Age, gender, social status and professional activity marking bearers create the integrated semantic net system which is the result of interaction between primary and secondary semantic components. These semantic components function within the semantic opposition. The primary semantic component of the marking bearers is evident and very well manifested. The biosocial group of marking bearers has purely biological, anatomical, and physiological background; to counterbalance the social stratification, group has chiefly foundation of social system structure, class stratification showing upperclass individuality. Using the function of the secondary semantic component, it is possible to notice some hidden semantic relations between the groups. Social status marking bearers singled out in naming units Elite Gentleman, Gentlemen only intense, Lady Million Eau My Gold, which are represented with lexical units gentleman, lady, prince, princess after having been as the secondary semantic component indicate the meaning of gender marking bearers, providing the difference between male (gentleman, prince) and female (lady, princess, l'imperatrice, queen) persons, but the primary semantic components demonstrate that these marking bearers belong to the social status subgroup. Lexical units lady, gentleman demonstrate also a secondary semantic component which may be regarded as the age of adult marking bearers. In the naming units Bod Man Warrior, Bod May Player, On duty women, On duty man active, Dior Homme Sport Maestro, Road Runner, Futurist, Perfectionist, Idealist, Lip Maestro their primary semantic component is recognized as the professional activity marking bearers (warrior, player, on duty, maestro, runner). These lexical units have secondary semantic components which function as age marking bearers (adults of active, professional age). Using the model of primary and secondary semantic components gives the opportunity of understanding the existence of integrated complex relations between two groups. The relations on the level of primary semantic components underline the significance of marking bearers according to the different groups (biosocial and social stratification). The relations on the level of secondary semantic components help to see the inner, hidden relations between groups when social status and professional activity marking bearers belonging to the social stratification group have the semantic component of age and gender marking bearers. These marking bearers which are connected with two groups (biosocial and social stratification). All the marking bearers create the semantic center of social stratification. Being the central bearers, they create the narrower sense aspect where social stratification meaning is given in an explicit way. Explicitness is the background for the semantic center.

The broader sense which forms the semantic periphery of social stratification is based on the implicit way. Implicitness is created involving symbolical marking bearers. Symbolism is the process of abstract concept representation using any real object. Symbols which are used for creating naming units function as the representative-associations of certain social relations. Implicit symbolical marking bearers of social stratification have connotative meaning. Within the group of symbolical marking bearers, it is possible to single out two smaller groups. The first one includes object symbols (subgroups of toponyms and gemonyms); the second one involves personal name symbols (subgroups of personal names and metonyms). Toponyms show their meaning if the dictionary definitions are analyzed. Tokyo: "the capital and largest city of Japan, and its main financial and business center. Tokyo is known for being one of the largest and busiest cities in the world" [11, p. 1748]. In the naming unit, Tokyo Fashion lexical unit Tokyo forms an association with professional activity marking bearers as it has semes financial business, busiest. In the naming units London Beat, Cuba New York potential semes financial, business are found in the dictionary definitions of lexical units London, New York. But if a detailed definition of New York is analyzed ("a city in the northeast of the USA that is an important center for finance, culture and entertainment" [11, p. 1107], it is possible to use New York not only as a symbol of business but as a place of entertainment according to the last seme in its definition. The same symbolic function of entertainment, carefree life is represented with the group of toponyms: Fidji; Rio de Janeiro; Santa Domingo; Cuba Copacabana; Las Vegas; Hawaiian SKones. Some symbol toponyms are used as components of naming units: Miami Party; Soho Chic. These symbols may be connected with social status marking bearers but their meaning is based on the potential (associative) seme entertainment and the collection of semantic associations: vacation; tourist industry; gambling; show; holiday resort; fashionable shops; a place of happiness; enjoyable. In the naming units Paris Premier Roses; Paris Rebel Collection the lexical unit Paris has the double symbolism, not only as a business center but also as a place of entertainment. Associative semes demonstrate that fact (country's business and financial center; romantic city; fashion industry). Object symbols of toponymical nature are assonant with social status marking bearers and professional activity ones, representing social stratification in an implicit way. Within the object symbol subgroup, it is possible to find out the naming units gathered together 
on the ground of using lexical units - gemonyms. Gemonyms grasp names of precious stones and metals. These substances are the equivalent of money (especially gold bullion for banking operations), but they are the symbols of power wealth. At the same time, these substances may also function as the attributes of social status. These substances have been used to make power regalia (crown treasures). Gemonyms have connotative relations with social status and professional activity marking bearers. Lexical unit Gold has the leading position and is used in naming units Euphoria Gold, Golden Peach; Precious Gold; Rare Gold. The dictionary definition of Gold shows its meaning: "a valuable soft yellow metal that is used to make coins, jewellery etc.; coins, jewellery etc. made of gold; the color of gold" [11, p. 696-697]. "Gold is a symbol of all that is superior, the glorified. Everything golden or made of gold tends to pass on the quality of superiority to its utilitarian function. Gold is also the essential element in the symbolism of the hidden or elusive treasure which is an illustration of the fruits of the spirit and of supreme illumination" [3, p. 120]. Lexical unit Gold is a frequent component of perfume and cosmetic naming units as it indicates a very popular in the society metal: Giordani Gold; Gleaming Gold; Diorific Gold shock; Simply Gold; 24k Simply Gold; 24k Golden Black; Cuba Gold; My Gold; Jivago 24k Gold; Liquid Gold euphoria men; Euphoria Liquid Gold. The lexical unit Platinum functions as a part of naming units: Platinum; Platinum Night; Samba Platinum; Platinum egoiste. This metal is the measure of wealth and refined taste; its dictionary definition demonstrates that: "a silver-grey metal that does not change colour or lose its brightness and is used in making expensive jewellery and in the industry" [11, p. 1251]. In naming units Silver; Glitter Mascara Silver lexical unit Silver is connected with the symbolic marking bearers of social stratification according to its dictionary definition: "a valuable shiny, light grey metal that is used to make jewellery, knives, coins etc." [11, p. 1537]. Dictionary definitions of all these precious metals have associative semes valuable, precious, expensive and these lexical units may function as symbolical marking bearers of social stratification. Here is a broader definition of lexical unit silver: "Silver is the second literature; often there is no distinction in meaning. Both "gold", and "silver" are synonyms for money in Greek, Latin, Hebrew, and many modern languages. But wherever there is ranking silver comes second as the monetary value of the metal is always less than of gold. As a bright, precious metal silver belongs to the classical gods only less insistently than gold. Apollo is particularly associated with a silver bow; "silver bow" is the title of his in the Iliad" [5, p. 196]. There are some precious stone names in the focus of objectssymbols. The lexical unit Diamond is the attribute of nobility, high social levels; it is used as a component of some naming units: White Diamonds Lustre; White Diamonds; Yellow Diamond; Versace Yellow Diamond; Diamonds for men; Black Diamond. Its dictionary definition emphasizes its price and value: "a transparent, extremely hard precious stone that is used in jewellery, and in the industry for cutting hard things" [11, p. 431].

Its association with wealth and power is underlined in the definition: "Like all precious stones, it partakes of the general symbolism of treasure and riches that is moral and intellectual knowledge" [3, p. 81]. Naming units Rare Sapphires; Loose Pearls intense illuminating effect; Sparkling Amethyst; Bright Crystal Absolute contains gemonyms - lexical units: Sapphire; Pearl; Amethyst; Crystal. All these lexical units are assonant with social status marking bearers because they are symbols of money, wealth, prosperity. The common seme that is in all dictionary definitions of these gemonyms is jewellery. Its definition also reveals the symbolic meaning as an attribute to wealth, money: "Objects made with valuable stones and is used for decoration" [11, p. 869]. The archeseme valuable shows the position of gemonyms as symbolical marking bearers of social stratification in an implicit way. Attribute precious: "something that is precious, valuable, and important; and should not be wasted or used without care; rare and worth a lot of money" [11, p. 1285]. The lexical unit money is an associative seme and shows the meaning in a clear way. Money: "what you earn by working and can use to buy things; someone's wealth, including all the property and other things own" [11, p. 1061-1062]. Symbolical marking bearers of social stratification include also personal name symbols. These name symbols are divided into Real Person Names and the clusters of Metonyms. Real Person Names are the perfume and cosmetic naming units (Paco Rabanne; Pierre Cardin; Burberry; Jean Paul Gaultier; Karl Lagerfeld) or are the components of naming units (Versace Eros; Dior Homme; Armani; Code; Chanel № 5; Real Calvin Klein). The implicit meaning of these symbolical marking bearers may be revealed using the fragments of these persons' biographies. There it is possible to find some sets of different semes. The first seme set includes businessman; businesswoman; family business, global president and manager; earned more money; global brand. These semes correlate with the professional activity marking bearers. The second seme set contains: elegant; luxury; luxury company; luxury fashion house; British Royal Family; lavish lifestyle; socialette heiress media personality. These semes correlate with the social status marking bearers. The cluster of Metonyms contains Antaneus; Eros; Athena. These names are associated with gods, semi gods, goddesses and have an implicit connotation with the social status marking bearers.

Conclusions. Social stratification (age, gender, social status, professional activity) marking bearers take place within the perfume and cosmetic goods naming units. These bearers are realized in two different ways: explicit (with the narrower sense) and implicit (with the broader sense). The explicit way involves two groups of bearers: the first group of biosocial indication (it includes the subgroup of gender marking bearers and the subgroup of age bearers). The second group of social stratification nature consists of social status and professional activity subgroups. The implicit way involves two groups of symbolical marking bearers. The first group is connected with object symbolisms. It includes subgroups of toponyms and gemonyms. The second group contains two subgroups too. The first one is created with real person names. The second one contains metonyms. The usage of the narrower sense marking bearers (age, gender, social status, professional activity) and the broader sense symbolical marking bearers (toponyms, gemonyms, real person names, metonyms). The integrated system of marking bearers demonstrates the complex nature of perfume and cosmetic naming units and their semantic peculiarities.

\section{Literature:}

1. Briot E. Fashion Sprayed and Displayed: The Market for Perfumery in Nineteenth-Century Paris Proceedings of the Economic History Society. Annual Conference, 2007. P. 69-72.

2. Chernatony L. de, Donald M. Mc, Wallace E. Creating Powerful Brands. London : Taylor and Francis, 2011. 249 p.

3. Cirlot J.E. A dictionary of symbols. London : Routledge Taylor and Francis, 2001. 398 p. 
4. Dixit S. Fine Fragrance Business Trends. Chemical Business. 2009. № 23. Vol. 6. P. 11-26.

5. Ferber M.A. Dictionary of Literary Symbols. Cambridge : Cambridge University Press, 1999. 347 p.

6. Galitska E.A. Social factor verbalization in the perfume and cosmetic naming. Science and Education. A New Dimension. Philology. 2016. № 25. Vol. 105. P. 20-23.

7. Harrison M.E. The Scented Word: Context, Intrigue, and the Problem of Olfactory L'teracy. Fragrances. - Supplement to Household and Personal Care Today. 2010. № 1. P. 6-10.

8. Jones G. Globalization and Beauty: A Historical and Firm Perspective. EURAMERICA. 2011. № 41. Vol. 4. P. 885-916.

9. Keller K.L., Heckler S.E., Houston M.J. The Effects of Brand Name Suggestiveness of Advertising Recall. Journal of Marketing. 1998. № 62. Vol. 1. P. 48-57.

10. Kohli C., Bahn D.W.La. Observations: Creating Effective Brand Names: A Study of the Naming Process. Journal of Advertising Research. 1997. № 37. Vol. 1. P. 67-75.

11. Longman Dictionary of Contemporary English / director Della Summers. Harlow : Pearson Longman, 2006. 1950 p.

12. Merskin D. Truly Toffee and Raisin Hell: A Textual Analysis of Lipstick Names. Sex Roles. 2007. № 56. P. 591-600.

13. Noppeney C. Consistent, Authentic and Emotional: Design-based innovation in Artistic Perfumery. Leading Innovation through Design. Proceedings of the DMI 2012 International Research Conference. 2012. P. 681-691.

14. Petty R.D. Naming Names: Trademark Strategy and Beyond: Part one. Selecting a Brand Name. Journal of Brand Management. 2008. № 15. P. 190-197.

15. Robertson K. Strategically Desirable Brand Name Characteristics. Journal of Product and Brand Management. 1992. № 1. Vol. 3. P. 62-72.

16. Walker R. A Challenging Global Climate for Fragrances. Global Cosmetic International. 2012. November. P. 26-29.

Гаврилюк О. О., Нікіфорова Є. Ю., Галицька Є. А. Маркувальні носії семантики соціальної стратифікації в парфумерно-косметичних назвах

Анотація. Стаття пов'язана 3 проблемою парфумерно-косметичної номінації в англійській мові. Особлива увага приділена відображенню ознак соціальної страти- фікації в номінативних одиницях, що містять маркувальні носії. Останні виявляють присутність ознак соціальної стратифікації в семантиці номінативних одиниць. Маркувальні носії розглядаються як номінативно-структурні компоненти або кластери цих компонентів, що мають у межах номінативних одиниць специфічну мовленнєву реалізацію та аранжирування. Одночасно ці маркувальні носії є представниками певного функціонального навантаження, що пов'язані 3 формуванням номінативних одиниць у їхньому семантичному аспекті. Ці маркувальні носії вказують (у межах мовленнєвого аспекту парфуменрно-косметичного товарного фрейму) на семантично-структурне і змістовно-наративне відображення наративної одиниці. У вужчому сенсі маркувальні носії групуються навколо двох гіпергруп. Перша гіпергрупа асоціюється з біосоціальними характеристиками, тоді як друга пов'язана із соціально-сегментаційними ознаками. Перша гіпергрупа розмежовується на дві групи, що в подальшому розділяються на чотири підгрупи. Перша підгрупа сформована маркувальними носіями віку. Друга складається 3 маркувальних носіїв роду (гендеру), третя сформована маркувальними носіями соціального статусу, а четверта містить маркувальні носії професійної активності. У широкому розумінні маркувальні носії можуть розглядатися як символічні маркувальні носії, що відображають соціальну стратифікацію імпліцитно. У цьому разі маркувальні носії із символічною конотацією зосереджені у межах двох груп. Перша група охоплює символи-об'єкти, тоді як друга група складається із символів-власних імен. Ці символічні маркувальні носії асоціюються або із символами-реальними об'єктами, або із символами-власними іменами. Символи-об'єкти розмежовуються на топоніми і героніми. Символи-власні імена розмежовуються на імена реальних осіб і міфоніми. Використання словникових дефініцій символічних маркувальних носіїв робить можливим ідентифікацію архісем і диференціальних сем. Ці семи є базовими критеріями для об'єднання символічних маркувальних носіїв у відповідні групи та підгрупи.

Ключові слова: архісема, диференціальна сема, номінативна одиниця, маркувальний носій, соціальна стратифікація, семантика, парфумерно-косметична назва. 